Available online on 15.02.2020 at http://ajprd.com
(c) 2013-20, publisher and licensee AJPRD, This is an Open Access article which permits unrestricted non-
commercial use, provided the original work is properly cited

Open $\odot$ Access

Research Article

\title{
Antibacterial Activity of Ethanolic Extract of Kitolod (Hippobromalongiflora) Leaf Against Staphylococcus aureus and Salmonella typhi
}

\section{Simanjuntak Helen Anjelina}

Department of Pharmacy, Sekolah Tinggi Ilmu Kesehatan Senior Medan, Medan, Indonesia.

\begin{abstract}
A B S T R A C T
Objective: The purpose of this study was to determine at what concentration of ethanol extract of kitolod leaves is active against Staphylococcus aureus and Salmonella typhi.

Methods: Ethanolic extract of Kitolod leaves was tested for phytochemical screening by using standard protocol. Antibacterial testing was using the diffusion disc method to measure the inhibition zone against the Staphylococcus aureus and Salmonella typhi with various concentration of Kitolod leaves extract $(6.25 \%, 12.5 \%, 25 \%, 50 \%$, and $75 \%)$.

Results: Phytochemical screening showed that ethanolic extract of Kitolod leaves contain alkaloids, flavonoids and saponins. The antibacterial inhibition of ethanol extract of kitolod leaves against Staphylococcus aureus and Salmonella typhi bacteria at a concentration of $75 \%$ had a diameter of 11.3 mm and $12.16 \mathrm{~mm}$ with a strong category.

Conclusions: Kitolod leaf could be use as a novel antibacterial agent.
\end{abstract}

Keywords: Extract, Antibacterial, Kitolod, Hippobromalongiflora,S. aureus, S. typhi

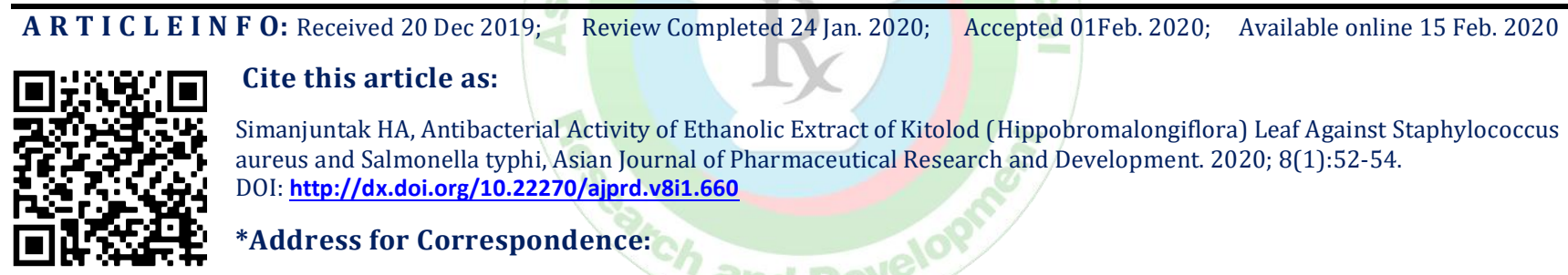

Simanjuntak Helen Anjelina, Department of Pharmacy, Sekolah Tinggi Ilmu Kesehatan Senior Medan, Medan, Indonesia.

\section{INTRODUCTION}

$\mathrm{M}$ edicinal plants have been known to cure various diseases since ancient times. This is due to the potential of chemical compounds found in these plants that can be used to synthesize new conventional medicines, one of which is the plant kitolod Hippobroma longiflora (L.) G. Don ${ }^{1}$. Kitolod plants are used to treat toothache, asthma, bronchitis, laryngitis, cataracts, wound medication, and cancer drugs ${ }^{2}$.Ethanol extract of kitolod leaf contain secondary metabolite compounds namely alkaloids, flavonoids, polyphenols, monoterpenoids, sesquiterpenoids, quinins and saponins ${ }^{3}$. According to Ibrahaim explains that the content of secondary metabolites in plants Chitolod has activities such as antioxidants, cytotoxics, anticancer, anti-inflammatory and antimicrobial ${ }^{4}$.Staphylococcus aureus is one of the important pathogenic bacteria associated with toxin virulence, invasive, and the body's resistance to antibiotics. Staphylococcus aureus infection is the main cause of skin, soft tissue, respiratory, bone, joint and endovascular disorders. Salmonella typhi is a pathogen that causes typhoid (enteric) fever, which is a systemic infection in humans caused by Salmonella serotypes, including Salmonella serotype Typhi ${ }^{6}$.This research is expected to provide information on secondary metabolite compounds found in chitolod leaves and the antibacterial activity of ethanol extracts of kitolod leaves against Staphylococcus aureus and Salmonella typhi.

\section{MATERIAL AND METHODS}

\section{Plant preparation}

Fresh kitolod leaves was collected from local area of from Bakal Julu Village (Dairi Regency North Sumatra Medan, Indonesia), and authenticated by Indonesian Institute of Sciences: Research Center ForBiology (No. 2347/MEDA/2019). Voucher specimen was deposited in the Pharmacognosy Laboratory, Sekolah Tinggi IlmuKesehatan Senior Medan.

\section{Extraction of kitolod leaves}

Kitolod leaves simplicia powder was extracted using maceration method with $96 \%$ ethanol solvent. Maceration is done by soaking the simplicia of kitolod leaves for 3 days with occasional stirring. The procedure is repeated 
until the color is clear. The results of maceration (maserate) were evaporated using a rotary evaporator to obtaincrude extract of Kitolod leaves.

\section{Phytochemical screening of various lotus leaf extract}

The crude extract of kitolod leaves was screening by using the standard protocol to know the presence of phytochemical compounds ${ }^{7}$.

\section{Antibacterial test}

Preparation of antibacterial test will begin with sterilizing the tools and materials to be used, rejuvenation of bacteria, making media, making bacterial suspense, making kitolod leaf extract test solutions and making comparative standard solutions. The determination of the antibacterial activity was carried out with sterilized NA media inserted into 20 $\mathrm{mL}$ sterile petri dishes each and allowed to condense at room temperature. The media was dropped with $0.1 \mathrm{~mL}$ of bacterial suspension test and flattened using an L bar until smooth and dry. Sterile disk paper with a diameter of $6 \mathrm{~mm}$ was dropped with ethanol extract $96 \%$ of kitolod leaves as much as $10 \mu \mathrm{L}$ with each concentration of $6.25 \%, 12.5 \%$, $25 \%, 50 \%$, and $75 \%$ and then placed on the media so that the solid that had been dripped with a test bacterial suspension, DMSO $10 \%$ as a negative control, and chloramphenicol as a positive control. Then incubated at $37^{\circ} \mathrm{C}$ for 24 hours and after incubation the clear zone was measured using calipers, three replications were performed.

\section{RESULT AND DISCUSSION}

\section{Phytochemical Screening}

Phytochemical screening results of kitolod leaves ethanol extract showed different phytochemical compounds (Table $1)$.
Table 1. Phytochemical screening of Kitolod leaves ethanolic extract

\begin{tabular}{|l|l|l|l|}
\hline No & Screening & Reagent & $\begin{array}{l}\text { Ethanolic } \\
\text { Extract }\end{array}$ \\
\hline 1 & Alkaloids & Mayer & Positive \\
\hline & & Dragenddroff & Positive \\
\hline & & Bouchardat & Positive \\
\hline 2 & Flavonoids & $\begin{array}{l}\mathrm{Mg}+\mathrm{HCl}+\mathrm{Amyl} \\
\text { Alcohol }\end{array}$ & Positive \\
\hline 3 & Saponins & Foaming Test & Positive \\
\hline 4 & Tannins & $\mathrm{FeCl}_{3} 1 \%$ & Negative \\
\hline 5 & Triterpenoid/Steroids & Liebermann Bouchard & Negative \\
\hline
\end{tabular}

\section{Antibacterial test}

Antibacterial activity testing of ethanol extract of kitolod leaves was carried out using the disk diffusion method, namely the determination of bacterial sensitivity with a particular substance that may have antibacterial activity using disc paper. Antibacterial testing was carried out with various concentrations of $6.25 \%, 12.5 \%, 25 \%, 50 \%$, and $75 \%$, chloramphenicol and DMSO. The results of testing the antibacterial activity of ethanol extract of chitolod leaves against Staphylococcus aureus and Salmonella typhi can be seen in Table 2 and Figure 1 below.

Table 2: Antibacterial result of Kitolod leaves ethanolic extract

\begin{tabular}{|l|l|l|}
\hline \multirow{2}{*}{ Concentration } & \multicolumn{2}{|l|}{ Zone of inhibition (mm) } \\
\cline { 2 - 3 } & Staphylococcus aureus & Salmonella typhi \\
\hline $75 \%$ & 11.3 & 12.6 \\
\hline $50 \%$ & 10 & 8.9 \\
\hline $25 \%$ & 8.83 & 7.6 \\
\hline $12.5 \%$ & 7.06 & 7.83 \\
\hline $6,25 \%$ & 0 & 7.66 \\
\hline Chloramphenicol & 28.66 & 30.5 \\
\hline DMSO & 0 & 0 \\
\hline
\end{tabular}

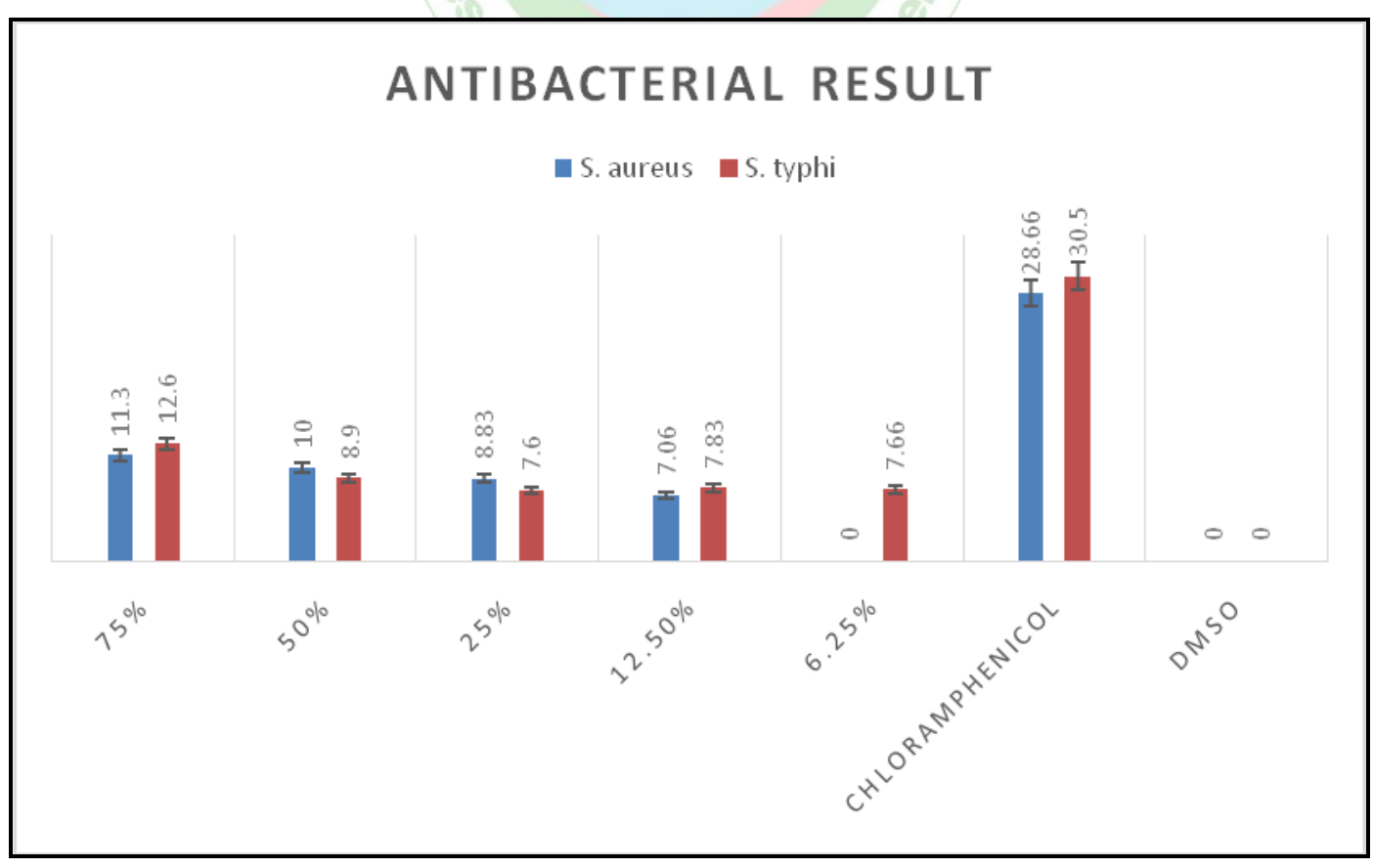

Figure 1: Antibacterial result of Kitolod leaves ethanolic extract

Based on Table 2 and Figure 1 it can be seen that $75 \%$ concentration of ethanol extract of kitolod leaves is effective in inhibiting the growth of Staphylococcus aureus and Salmonella typhi with inhibition zone diameters of $11.3 \mathrm{~mm}$ and $12.6 \mathrm{~mm}$, which are classified as strong criteria. Whereas the concentration of $6.25 \%$ has the ability to inhibit the growth of Salmonella typhi bacteria compared to Staphylococcus aureus. According to Davis and Stout, explain that the criteria for antibacterial inhibition consist 
of $\geq 20 \mathrm{~mm}$ is very strong, $10-20 \mathrm{~mm}$ is strong, $5-10 \mathrm{~mm}$ is moderate and $\leq 5 \mathrm{~mm}$ is weak $^{8}$.

In positive controls using standard chloramphenicol with a concentration of $30 \mathrm{mg} / \mathrm{ml}$. Chloramphenicol works by inhibiting protein synthesis in bacterial cells by reversibly binding to the $50 \mathrm{~s}$ ribosome subunit ${ }^{9}$. The negative control used was DMSO with a concentration of $10 \%$. In this study negative control DMSO has no clear zone, so DMSO can be said to not be able to inhibit bacterial growth.

alkaloids can disrupt the constituent components of peptidoglycan on bacterial cells so that the cell wall layers are not formed intact and cause cell death. Another mechanism of antibacterial alkaloids is that the alkaloid component is known as a DNA accelerator and inhibits bacterial cell topoisomerase enzymes ${ }^{11}$.

Flavonoids provide bacteriolytic effects, inhibit protein synthesis, DNA synthesis, RNA and damage cell membrane permeability ${ }^{12}$. According to $\mathrm{Wu}$ et al, flavonoids have antibacterial activity because of the ability of flavonoids to interact with cell membranes and affect cell membrane bioactivity and it has been reported that flavonoids are able to reduce the fluidity of bacterial cell membranes that is directly related to damage to cytoplasmic membranes or indirect damage through autolysis / weakening of the cell wall and consequently osmotic lysis ${ }^{13}$.

\section{REFERENCES}

1. Baibado JT, Hon YC. Biological Functions of The Metabolites FromEuphorbia hirta L. International Journal of Pharmaceutical and Biological Science Archive 2015; 3(1): 27-9.

2. Utami P. BukuPintarTanamanObat. Jakarta: Penerbit AgromediaPustaka; 2008. p. 147-8.

3. Aqila FN, Sri Agung FK, Yopi I. Antituberculosis Activity Test of Kitolod Leaf Ethanol Extract (Laurentia longiflora (L). Paterm). International Journal of Scientific Engineering and Applied Science 2017;7(7)

4. Ibrahim S., Darma RR and Afrizal. Isolation and Elucidation Structure of Triterpenoids from Hippobroma longiflora Leaf Extract and Tested of Antibacterial Activity. Journal of Chemical nd Pharmaceutical Research 2017; 9(11):205-8.

5. Tong SYC, Davis JS, Eichenberger E, Holland TL, Jr VGF. Staphylococcus aureus Infections: Epidemiology, Pathophysiology. Clinical Microbiology Reviews 2015; 28(3):602-31.

6. Santos R1., Shuping Z., Renee MT., Robert A.K., L. Garry A., Andreas J.B. Animal Models of Salmonella Infections: Enteritis Versus Typhoid Fever. Microbes and Infection 2001; 3:1335-44.

7. Sinaga SM, Haro G, Sudarmi S, Iksen I. Phytochemical Screening and Antihyperglycemic Activity of Ethanolic Extract of Coriandrum sativum L. Leaf 2019; 12(4):1992-6.
Ethanol extract $96 \%$ of active chitolod leaves as antibacterial due to chemical components contained in the extract. Based on phytochemical screening, ethanol extract of kitolod leaves contain alkaloid, flavonoid, and saponin compounds. The mechanism of action of alkaloids as an antibacterial is by inhibiting the synthesis of nucleic acids, because it can inhibit the enzymes dihydrofolate reductase and topoisimerase $\mathrm{I}^{10}$. According to Karou et al.,

The mechanism of action of saponin as an antibacterial causes lysis of the bacterial cell wall and leakage of AKP (Alkaline Phosphate), an increase in saponin concentration causes the protein to dissolve, causing intercellular compounds to diffuse through the outer membrane and cell wall. This causes the cytoplasm to leak out of the cell resulting in cell death ${ }^{14}$.

\section{CONCLUSIONS}

The ethanol extract of Kitolod leaves has a group of secondary metabolites including alkaloids, flavonoids, and Saponins. The ethanol extract of Kitolod leaves has effective antibacterial activity against Staphylococcus aureus and Salmonella typhi bacteria with a concentration of $75 \%$ with a strong category.

\section{ACKNOWLEDGMENTS}

Authors wish to thank to Deby Geovani Hutasoit for her help about this research.

8. Davis WW, Stout TR. Disc Plate Method of Microbiological Antibiotic Assay: Applied and Enviromental Microbiology 2009; 22 (4):666-70.

9. Kasten, MJ. Clindamycin, Metronidazole, and Chloramphenicol. Mayo ClinicProceedings.1999; 74(8):823-833.

10. Cushine TPT, Benjamart C, LambAJ. Alkaloids: An Overview of Their Antibacterial,Antibiotic - Enhancing and Antivirulence Activities. International Journal of Antimicrobial Agents2014; 44:377-86.

11. Karou D, Savadogo A, CaniniA, Yameogo S, Montesano C, Simpore J, Colizzi V, Traore AS. Antibacterial activity of alkaloids from Sidaacuta 2005; 4(12):1452-7.

12. Dzoyem JP, Hiroshi H, Barthelemy N, Bonaventure TN, Kazuhisa S. Antimicrobial Action Mechanism of Flavonoids From Dorstenia Spesies. Drug Discoveries \& Therapeutic 2013; 7(2):66-72.

13. Wu T, Mengying H, Xixi Z, Ying Z, Tianfu Q, Siyi P, Xiaoyun X. A StructureActivity Relationship Study of Flavonoids As Inhibitors of E. coli By Membrane Interaction Effect. Biochimica et Biophysica Acta2013;2751-6.

14. Khan MI, Abdulatef A, Jin HS, Jun SB, Min YK,Jong DK. Green Tea Seed Isolated Saponins Exerts Antibacterial Effects Against Various Strains of Gram Positive and Gram Negative Bacteria A Comprehensive Study In Vitro and In Vivo.Evidence-Based Complementary and Alternative Medicine2018;1-12. 